\title{
Results of palaeofaunal research
}

\author{
Trevor H. Worthy \\ School of Biological, Earth and Environmental Sciences, The University of New South Wales
}

Atholl Anderson

Department of Archaeology and Natural History, The Australian National University

\section{Introduction}

In this chapter, we describe the results of identifications of the faunal remains described in Chapter 2. We restrict the results to data from the fossil sites rather than the archaeological sites, which are described in Chapter 10. Analyses were carried out by Worthy using the reference collections noted in Chapter 10, which include relatively modern material in order to examine changes in the Fiji fauna.

The following abbreviations have been used for both single and plural reference to the elements: cmc, carpometacarpi; cor, coracoids; fem, femora; fib, fibulae; hum, humeri; pt, part; quad, quadrates; rad, radii; scap, scapulae; stern, sterna; tmt, tarsometatarsi; and tib, tibiotarsi. When listing material, bones are sometimes identified as left $(\mathrm{L})$ or right $(\mathrm{R})$ elements. $\mathrm{L}$ or $\mathrm{R}$ prefixed by 'p', 's' or 'd' indicates 'proximal', 'shaft' or 'distal' part of the element respectively, e.g. $\mathrm{pR}$ fem means the proximal part of a right femur. Anatomical nomenclature for specific bone landmarks follows Baumel and Witmer (1993), but terms are Anglicised after first mention. Some common terms are abbreviated as follows: proc. for processus; artic. for articularis.

\section{Owl middens - insights into modern faunas}

In many of the sites described in the preceding chapter, middens accumulated by the barn owl (Tyto alba) were present (Table 1). In several cases, the bone deposits were relatively thin $(<10$ $\mathrm{cm}$ ) and generally they overlay archaeological deposits, indicating initiation of deposition after human use of the site. At Nabalabalagita Cave, the test pit indicated abundant bones of Rattus exulans to $45 \mathrm{~cm}$ depth. They are probably derived from owl midden, but human use of the cave is indicated by archaeological material to $62 \mathrm{~cm}$ depth. At the Tavuni site near Toga, the sediment containing owl-derived fauna and Tyto bone extended to $45 \mathrm{~cm}$ depth, and there, also, human influence in the site extended to about $60 \mathrm{~cm}$ depth. While still dominated by Rattus exulans, bones of $R$. praetor, Gallicolumba stairii and Porphyrio porphyrio are probably several hundred years old. In no case was there evidence of owl-midden deposits in sediments older than the period of human colonisation. 
Table 1. Faunas from barn owl (Tyto alba) sites showing NISP.

\begin{tabular}{|c|c|c|c|c|c|c|}
\hline Species & Common name & VSS & Buk & Tav & Q2 & Nab \\
\hline *Rattus exulans & Pacific rat & $100 \mathrm{~s}$ & $100 \mathrm{~s}$ & $100 \mathrm{~s}$ & $100 \mathrm{~s}$ & $100 \mathrm{~s}$ \\
\hline${ }^{*}$ Mus musculus & Mouse & & 21 & 73 & 88 & 6 \\
\hline${ }^{*}$ Rattus rattus/norvegicus & Rat & 64 & & 17 & & 5 \\
\hline *Rattus ?praetor & Rat & & & 4 & & \\
\hline Emballonura semicaudata & Microbat & & 54 & 2 & 4 & \\
\hline Tyto alba & Barn owl & 5 & 4 & 4 & 8 & 1 \\
\hline Egretta sacra & Reef heron & & 24 & 100 & & \\
\hline Halcyon chloris & White-collared kingfisher & & & & 1 & 3 \\
\hline Collocalia spodiopygia & White-rumped swiftlet & & 127 & 9 & 158 & \\
\hline Gallicolumba stairii & Friendly ground dove & & & 1 & & \\
\hline Ptilinopus perousii & Many-coloured fruit dove dove & & 2 & & & \\
\hline Ptilinopus luteovirens & Golden dove & & & & & $? 1$ \\
\hline Poliolimnas cinereus & White-browed crake & 8 & & & & \\
\hline Porzana tabuensis & Spotless crake & 5 & & & & \\
\hline Porphyrio porphyrio & Purple swamphen & & & 1 & & \\
\hline Foulehaio carunculatus & Wattled honeyeater & & & & & 2 \\
\hline${ }^{*}$ Acridotheres fuscus & Indian myna & & & 13 & & 4 \\
\hline *Pycnonotus cafer & Bulbul & & 58 & & 1 & 45 \\
\hline Aplonis tabuensis & Fiji starling & 1 & & & & \\
\hline Turdus poliocephalus & Island thrush & & 2 & & & \\
\hline Zosterops ?lateralis & Fiji white-eye & 5 & 25 & & & 30 \\
\hline Erythrura cyanovirens & Parrot bill finch & & & & & 1 \\
\hline Undetermined passerines & & & 7 & 6 & & $Y$ \\
\hline Gehyra oceanica & Gecko & 2 & 5 & 7 & & 18 \\
\hline Nactus pelagicus & Gecko & 1 & & 2 & & \\
\hline Gecko sp. indet & Gecko & 17 & & & 2 & \\
\hline Skink sp. indet & Skink & 6 & & & & \\
\hline Brachylophus ?vitiensis & Banded iguana & & & & 1 & \\
\hline
\end{tabular}

VVS - Volivoli Swamp site, Buk - Bukusia, Tav - Tavuni at Toga, Q2 - Qaranioso \#2 at Tau, Nab - Nabalabalagita Cave. 'Y' indicates the taxon was present. * means taxon is introduced. While rats appear to dominate these assemblages there is a consistent high diversity of birds and other vertebrates present.

The owl middens are observed as large surface deposits of rat bones. While most bones appeared to be whole, bulk samples show many are fragmented. Most are of the Pacific rat (Rattus exulans), but large numbers of geckos and a lesser number of birds are always present. Samples from such sites were collected to compare to the older fossil sites and provide indications of modern deposition in caves. It was hoped these could be compared to prehistoric owlaccumulated faunas, but none of those were found.

In all sites, rodents dominated the faunas (Table 1), with Rattus exulans most common. However, larger rats were also present, with Rattus praetor at deeper levels in one site, and Rattus rattus/norvegicus in surface deposits with Mus musculus. The small bat Emballonura semicaudata was common in some sites, where suitable roosting caves were present nearby. At least 17 species 
of birds plus other undetermined passerines were recorded from these owl middens. Two geckos and the banded iguana complete the fauna.

The fauna in each site appear to have been highly influenced by the local environment and the availability of prey species. For example, the small bat Emballonura and the swiftlets Collocalia were only present when there were caves near the sites, and then their bones were common, indicating they were favoured owl prey. The Volivoli Swamp site was the only one near a wetland and it was also the only one that had wetland birds such as white-browed crake Poliolimnas cinereus and spotless crake Porzana tabuensis. Fish bones were also present and, together with the crake bones, indicate the owl foraged over the wetland. The modern deposits often contained historically introduced birds, such as Indian myna Acridotheres fusca and bulbul Pycnonotus cafer, which, together with white-eyes Zosterops lateralis, were often the most common birds in the site. These taxa indicate that the owls were hunting in open grassland-shrubland habitats rather than in closed forest. One species notable by its absence among these faunas was the long-tailed cuckoo Eudynamis taitensis. Its bones were common in owl middens on Vatulele Island (see below), and this observation bears out the observations of local ornithologists (D. Watling, pers. comm., Environment Consultants, Fiji) that the long-tailed cuckoo is rare or absent on Viti Levu, yet common on smaller islands.

The most important conclusion from these data is that humans were already present in Viti Levu, and had been for some time, before barn owls Tyto alba arrived. The presence of suitable rodent prey introduced by people presumably at or near colonisation about 3000 years ago (Anderson and Clark, 1999; White et al. 2000) was probably the prerequisite that allowed barn owls, which are specialist predators of small mammals and specifically rodents, to self-colonise, presumably from the Solomon Islands.

\section{The fossil faunas}

Fossil vertebrate faunas were obtained from five main sites: Volivoli \#1, Qaranivokai, Wainibuku Cave, Udit Tomo and Vatumu. Isolated finds were made at Delaniqara at Wailotua, Bukusia and Qaranioso. The fossil faunas available from these sites reveal a minimum of 11 herpetofaunal species, 24 birds plus at least four undetermined passerines, and four bats (Table 2) (Worthy and Anderson 1999; Worthy et al. 1999; Molnar et al. 2002; Pregill and Worthy 2003; Worthy 2000a, 2001a, b, 2003, 2004). Of great significance, this fossil fauna revealed the presence of some extinct taxa, of which several are sufficiently large to be termed megafauna. Foremost among these were herpetofaunal species: a terrestrial crocodilian, a giant iguana, a giant frog and a tortoise. Among the birds were a giant flightless megapode and an equally large flightless pigeon, rivalling the dodo in size. Other extinct species include another megapode, a large fruit pigeon, and another large rail, in addition to the historically extinct barred-wing rail Gallirallus $(=$ Nesoclopeus $)$ poicilopterus, a snipe and a duck.

\section{Herpetofauna}

Three species of frog are represented. Bones of the two extant species, Platymantis vitiensis and P. vitianus, are present, with those of a newly discovered extinct species named Platymantis megabotoniviti (Worthy 2001a). Growing to about $150 \mathrm{~mm}$ snout-vent length, the latter was a very much larger and more robust ground frog than P. vitianus. Platymantis megabotoniviti was found in most fossil sites in Viti Levu (Figure 19).

Iguana fossils include some attributable to one of the extant species, but many are of a new, extinct giant iguana up to $1.5 \mathrm{~m}$ long (Worthy et al. 1999), recently named Lapitiguana impensa (Pregill and Worthy 2003). This iguana has been found in four sites (Volivoli \#1, Qaranivokai, 
44 Trevor H. Worthy and Atholl Anderson

Table 2. A list of taxa and NISP recorded from the main fossil sites in Viti Levu.

\begin{tabular}{|c|c|c|c|c|c|c|c|c|}
\hline Species & Common Name & Volivoli I & Qaranivokai & Wainibuku Cave & Udit Pitfall Cave & Vatumu & Wailotua & Joskes Thumb \\
\hline †Platymantis megabotoniviti & Giant ground frog & 36 & 795 & 53 & 6 & 11 & 1 & \\
\hline Platymantis vitiensis & Fiji tree frog & & 15 & & & 2 & & \\
\hline Platymantis vitianus & Fiji ground frog & 4 & 375 & & & 3 & & \\
\hline Gehyra aff. G. vorax & Large gecko & & 9 & & & 1 & & \\
\hline Gecko sp. & & & 13 & & & & & 1 \\
\hline Skink large sp. & & & 2 & & & & & \\
\hline †Lapitiguana impensa & Giant iguana & 35 & 134 & & & & & \\
\hline Brachylophus ?vitiensis & Modern iguana & 1 & 3 & & & & & \\
\hline Candoia sp. & Boa & 1 & & 157 & & & & \\
\hline †Volia athollandersoni. & Land crocodilian & 13 & & 112 & & & & \\
\hline †Tortoise nsp & Tortoise & 1 & & & & & & \\
\hline ? Tortoise nsp fragments & ?Tortoise & 13 & & & & & & \\
\hline Pseudobulweria rostrata & Tahiti petrel & & & & & 6 & & \\
\hline Pterodroma ?brevipes & Collared petrel & & & & & 2 & & 180 \\
\hline Pterodroma leucoptera & New Caledonian petrel & & & & & & & 1 \\
\hline Pterodroma externa or Pt. cervicalis & Juan Fernandez petrel & & & & & & & 5 \\
\hline Nesofregetta albigularis & White-throated storm petrel & & & & & & & 4 \\
\hline Puffinus Iherminieri & Audubon's shearwater & & & & & & & 20 \\
\hline Sterna fuscata & Sooty tern & & & & & & & 4 \\
\hline †Vitirallus watlingi & Viti Levu rail & 7 & 544 & & 1 & & & \\
\hline Gallirallus philippensis & Banded rail & & 5 & & & & & \\
\hline †Nesoclopeus poicilopterus & Barred-wing rail & & & 2 & 2 & & 18 & \\
\hline †Rail indet sp. 1 & ?Gallinule & & & 1 & 2 & & & \\
\hline †Megavitiornis altirostris & Giant megapode & 7 & 6 & 17 & 200 & & 5 & \\
\hline †Megapodius amissus & Viti Levu scrubfowl & 2 & 2 & & 89 & & & \\
\hline †Anas sp. indet. & Fiji teal & & & & & 1 & & \\
\hline Natunaornis gigoura & Giant pigeon & 10 & 16 & 13 & 29 & & & \\
\hline Columba vitiensis & White-throated pigeon & & 2 & & & & & \\
\hline Ducula latrans & Peale's pigeon & & 3 & & & 3 & & 53 \\
\hline †Ducula sp. cf D. lakeba & Large fruit pigeon & 1 & & 1 & 1 & 2 & & \\
\hline Gallicolumba stairii & Friendly ground dove & & & & & 24 & & \\
\hline Ptilinopus?lutiovitrens & Golden dove & & 1 & & & & & \\
\hline Ptilinopus perousii or $P$. luteovirens & Many-coloured or golden dove & & & & & 7 & & \\
\hline Ptilinopus sp. indet & Indet dove sp. & & & & & & & 3 \\
\hline Prosopeia personata & Musk parrot & & 31 & & & 2 & & 6 \\
\hline Vini solitarius & Collared lory & & & & & 1 & & 8 \\
\hline †Coenocorypha miratropica & Fiji snipe & & & & & 17 & & \\
\hline Accipiter rufitorques & Fiji goshawk & & & & & & & 39 \\
\hline Halcyon chloris & White-collared kingfisher & & & & & & & 1 \\
\hline Aplonis tabuensis & Polynesian starling & 1 & 3 & & & & & 2 \\
\hline Rhipidura cf spilodera & Spotted fantail & & 1 & & & & & \\
\hline Zosterops sp. & White-eye & & 1 & & & & & \\
\hline Foulehaio carunculata & Wattled honeyeater & & 1 & & & & & \\
\hline Gymnomyza viridis & Giant forest honeyeater & & & & & & & 5 \\
\hline Collocalia spodiopygia & Swiftlet & & & & & 1 & & \\
\hline Turdus poliocephalus & Island thrush & 1 & 7 & & $? 1$ & & & \\
\hline Passerine sp. & Small perching birds & & 10 & & & $7(4 \mathrm{sp})$ & & \\
\hline Pteropus tonganus & Large fruit bat & 2 & & & $? 1$ & $? 1$ & & 204 \\
\hline Notopteris macdonaldi & Small fruit bat & & 10 & 647 & & 34 & 209 & \\
\hline Emballonura semicaudata & Small bat & 3 & 98 & 2 & & 14 & & \\
\hline Chaerephon bregullae & Fijian mastiff bat & & & 6 & & & & \\
\hline
\end{tabular}

† Species globally extinct. Joskes Thumb is attributed to falcon predation, and is after Worthy (2000b) with addition of new material collected. 
Bukusia, Qaranioso), all in western Viti Levu (Worthy and Anderson 1999). Its large size is unrivalled in the Pacific, and also indicates that it was a terrestrial species (Figure 20). It has not been found in the wetter rainforest regions of the east despite the presence there of suitable fossil sites, indicating it favoured drier habitats. Banded iguanas in Fiji have recently been shown to comprise three distinct species, with Brachylophus bulabula erected for populations formerly known as B. fasciatus in the wet forests of Viti Levu, Vanua Levu and Kadavu (Keogh et al. 2008). Populations in the dry vegetation zones of the northwestern side of Viti Levu and offshore islands are B. vitensis, and B. fasciatus is now restricted to populations in the Lau Group. We follow this nomenclature here, but note that the referral of iguana bones from Vatulele or Sigatoka to either B. vitiensis of B. bulabula is problematic, as extant populations, if present, have not been identified (Keogh et al. 2008).

The new species (and genus) of extinct terrestrial crocodilian Volia athollandersoni and the tortoise were both found in Volivoli \#1 on the first investigation (Worthy et al. 1999). Remains of the tortoise have not been identified with certainty from any other site. The only identifiable bone, although there are several fragments with internal turtle osteological morphology, is an ungual, which is similar to that of the meiolaniids, or terrestrial horned turtles, known from, for example, New Caledonia and Lord Howe Island.

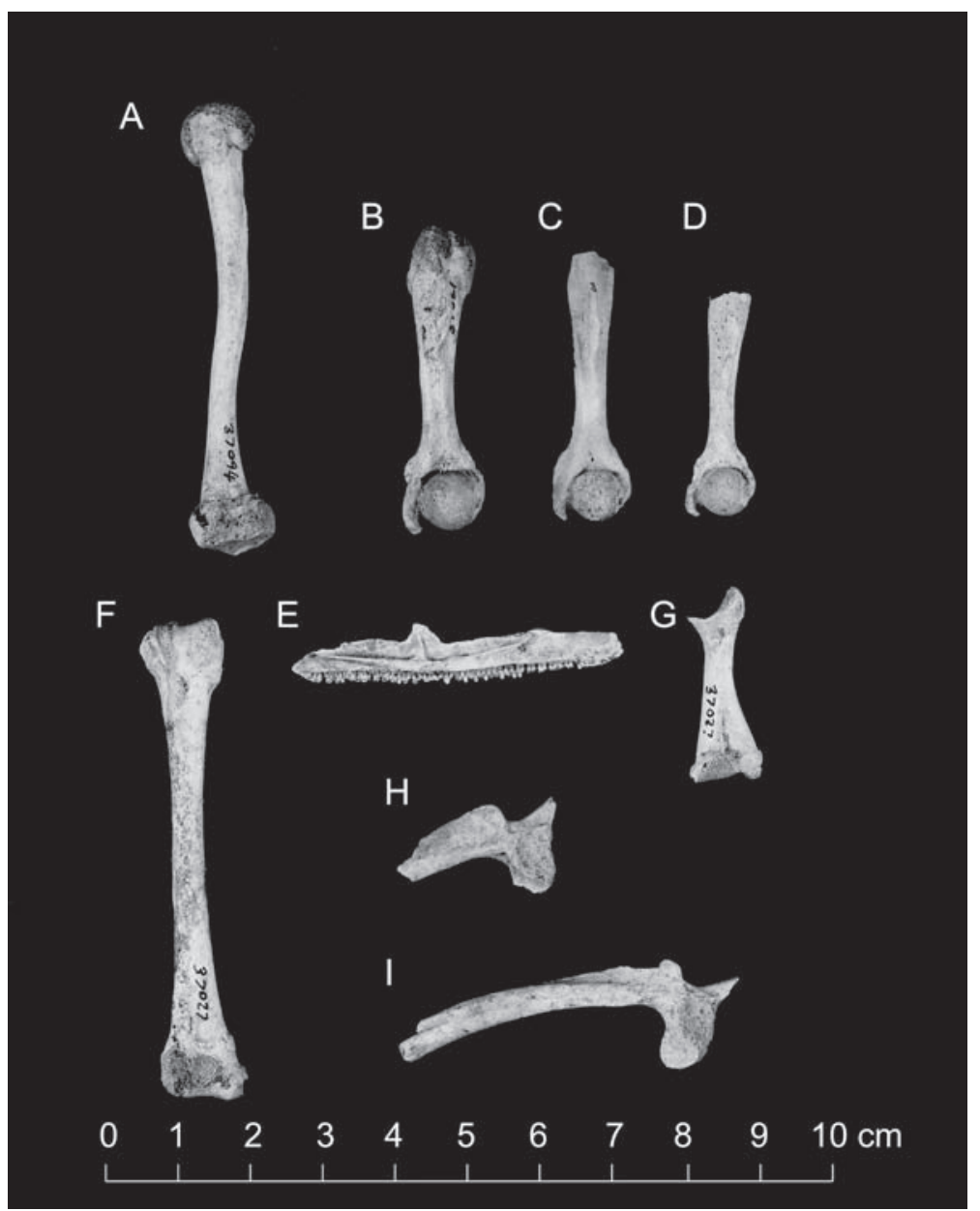

Figure 19. Selected bones of Platymantis megabotoniviti. A, femur MNZ S37094. B-D, adult left humeri in ventral view: S37027, S37068 and S37065. E, right maxilla S37061 in lingual view. F, left tibiofibula S37027 in anterior view. G, right radioulna S37027 in lateral view. H-I, left ilia S37057C and S37057A in lateral view. Reproduced from Worthy (2001a) with the permission of Palaeontology.

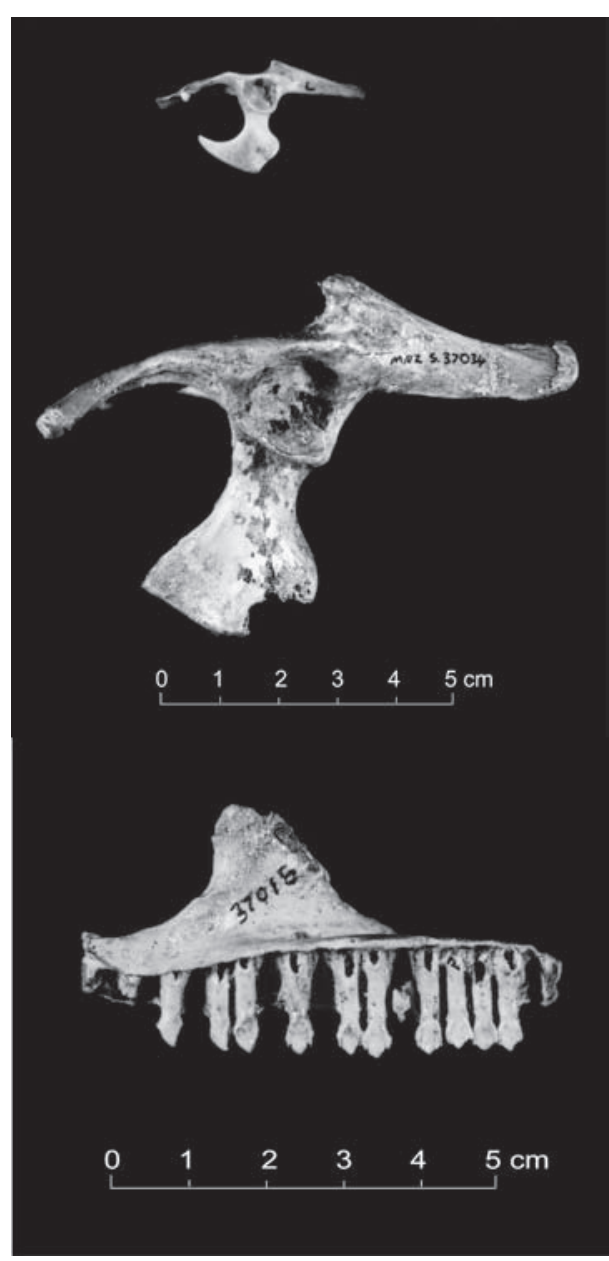

Figure 20. Giant iguana (Lapitiguana impensa) remains. Bottom, right maxilla (MNZ S37015) lingual view. Middle and top, pelves (left side) of modern B. vitiensis and Lapitiguana impensa (MNZ S37034). 
The crocodilian Volia athollandersoni is represented by material from Volivoli \#1 and Wainibuku Cave in the west and east of Viti Levu respectively (Figure 21). The better-preserved remains found in Wainibuku Cave have enabled the species to be described (Molnar et al. 2002). It is a terrestrial species most similar to Mekosuchus inexpectatus (Balouet and Buffetaut 1987) from New Caledonia and M. kalpokasi from Vanuatu (Mead et al. 2002), as well as fossil mekosuchine taxa from Australia (Molnar et al. 2002). Volia athollandersoni grew to at least $3 \mathrm{~m}$ in length.

The remaining fossil herpetofauna includes remains of a boid snake, presumably the extant Candoia bibronii, and undetermined skinks and geckos, including large (ca. 20-30 cm long) species of each.

\section{Avifauna}

The 24 taxa of birds so far known from these fossil faunas, even when augmented by at least four undetermined passerines, is a considerably smaller total than the 47 known historically from Viti Levu (Watling 1982). However, eight of the fossil taxa are newly discovered, extinct taxa. Most of the fossil species are ground-dwelling species, with canopy-dwelling forest species under-represented, and wetland taxa virtually absent.

Megapodes are one of the most characteristic ground birds of the South Pacific, with either extant or extinct species spread from Indonesia across the Pacific to Western Samoa (Jones et al. 1995; Steadman 1999, 2006a). The largest and most unusual species is Sylviornis

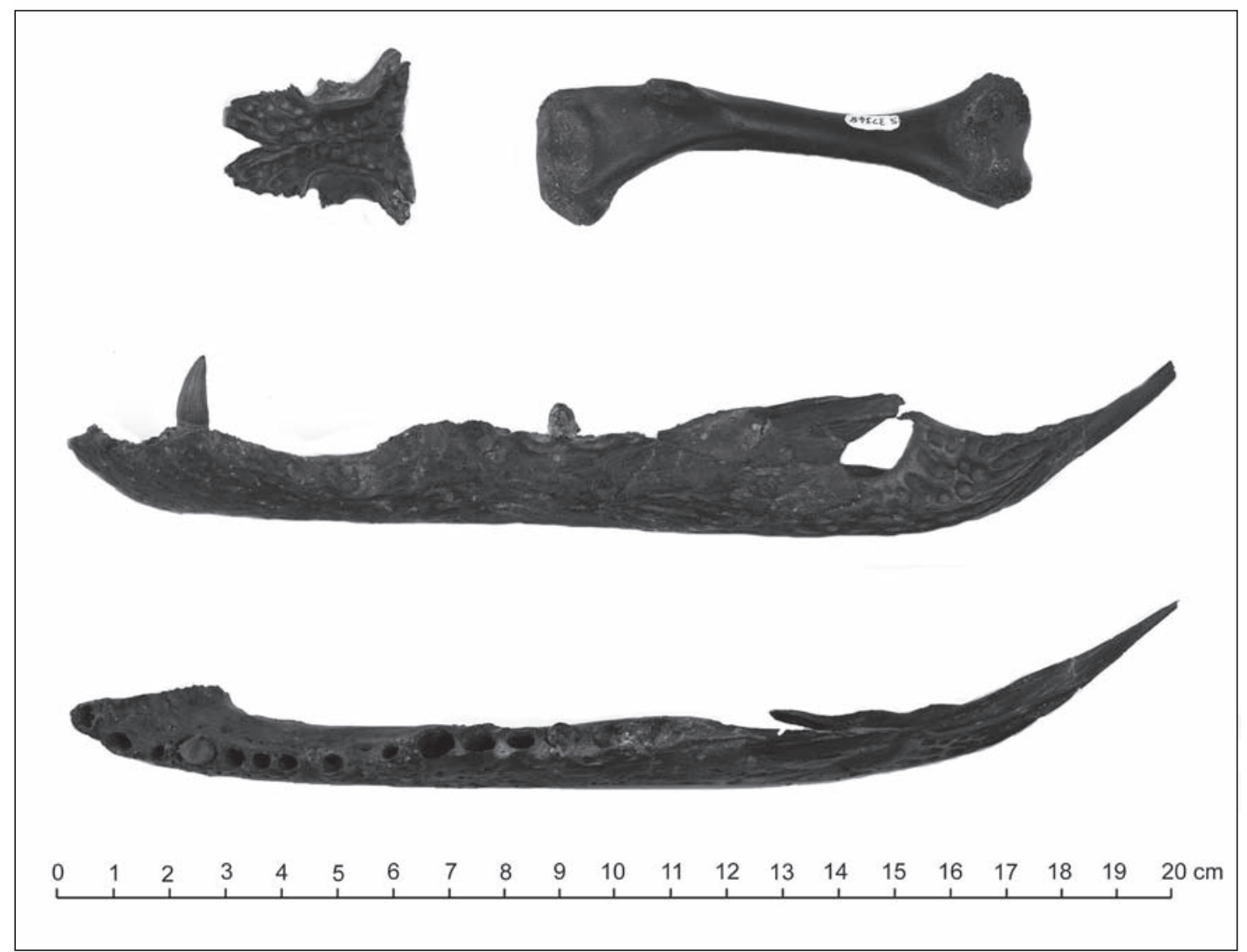

Figure 21. Terrestrial crocodilian (Volia athollandersoni) remains. Top left, coalesced parietals (MNZ S37342) dorsal view. Top right, humerus (right) (MNZ S37348). Middle, mandible (MNZ S37332) lateral view. Bottom, mandible (MNZ S37332) dorsal view. 
neocaledoniae from New Caledonia (Poplin and Mourer-Chauviré 1985; Balouet 1991), but the fossils discovered in Viti Levu reveal a smaller, but still very large species. Recently described as Megavitiornis altirostris (Worthy 2000a), this flightless species was perhaps up to $15 \mathrm{~kg}$ in weight and stood near $1 \mathrm{~m}$ tall. Its bones were found in Volivoli \#1, Qaranivokai, Udit Cave and Delaniqara at Wailotua, so the species lived in both wet and dry habitats (Figures 22

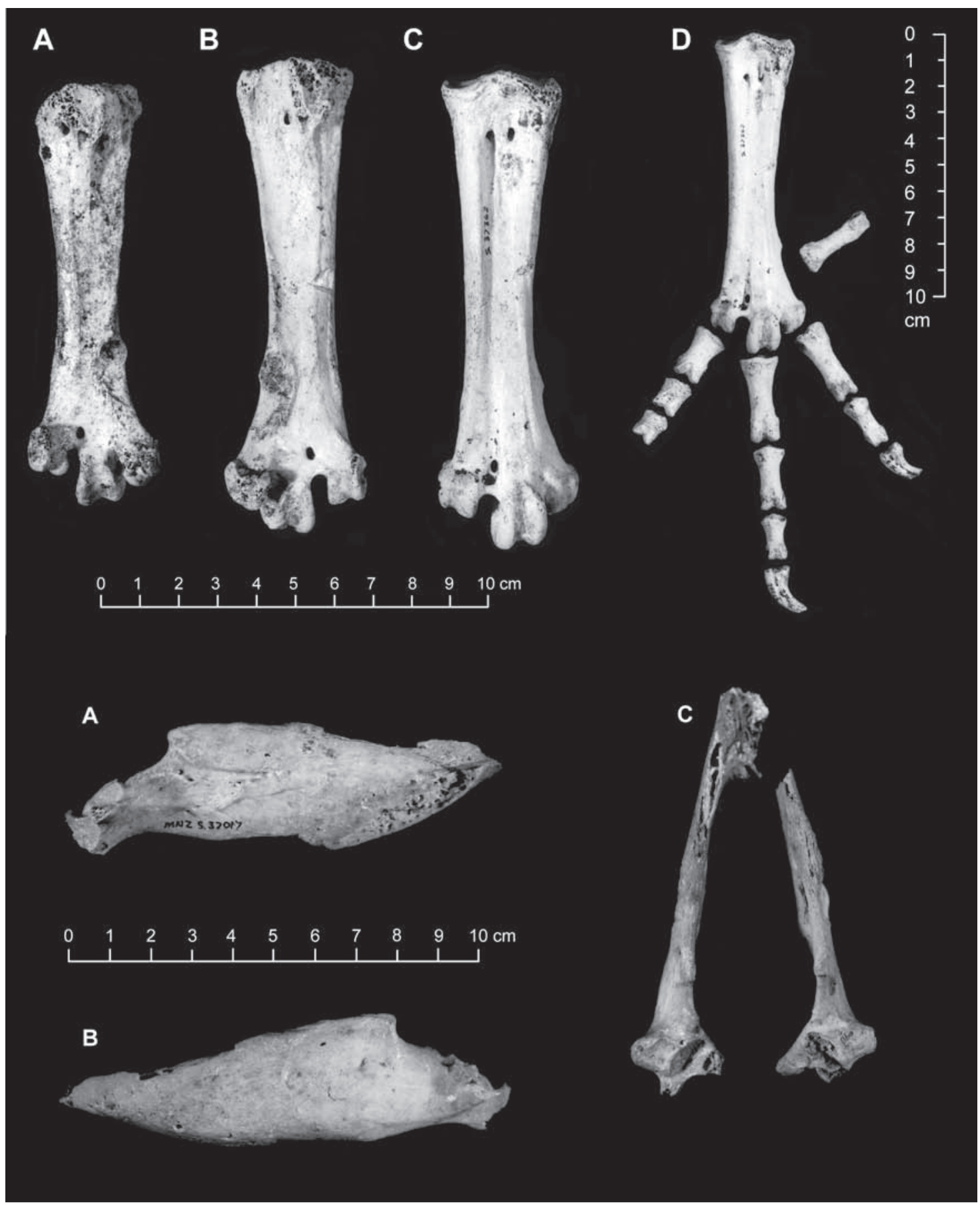

Figure 22. Top, Tarsometatarsi and phalanges of the giant megapode Megavitiornis altirostris from Viti Levu. A, paratype MNZ S37369; B-D, holotype MNZ S37362. Reproduced from Worthy (2000a) with the permission of the Royal Society of New Zealand. Bottom, the incredibly stout mandible of Megavitiornis altirostris, MNZ S37017 in A, medial, B, lateral, and C, dorsal, aspects. Reproduced from Worthy (2000a) with the permission of the Royal Society of New Zealand. 


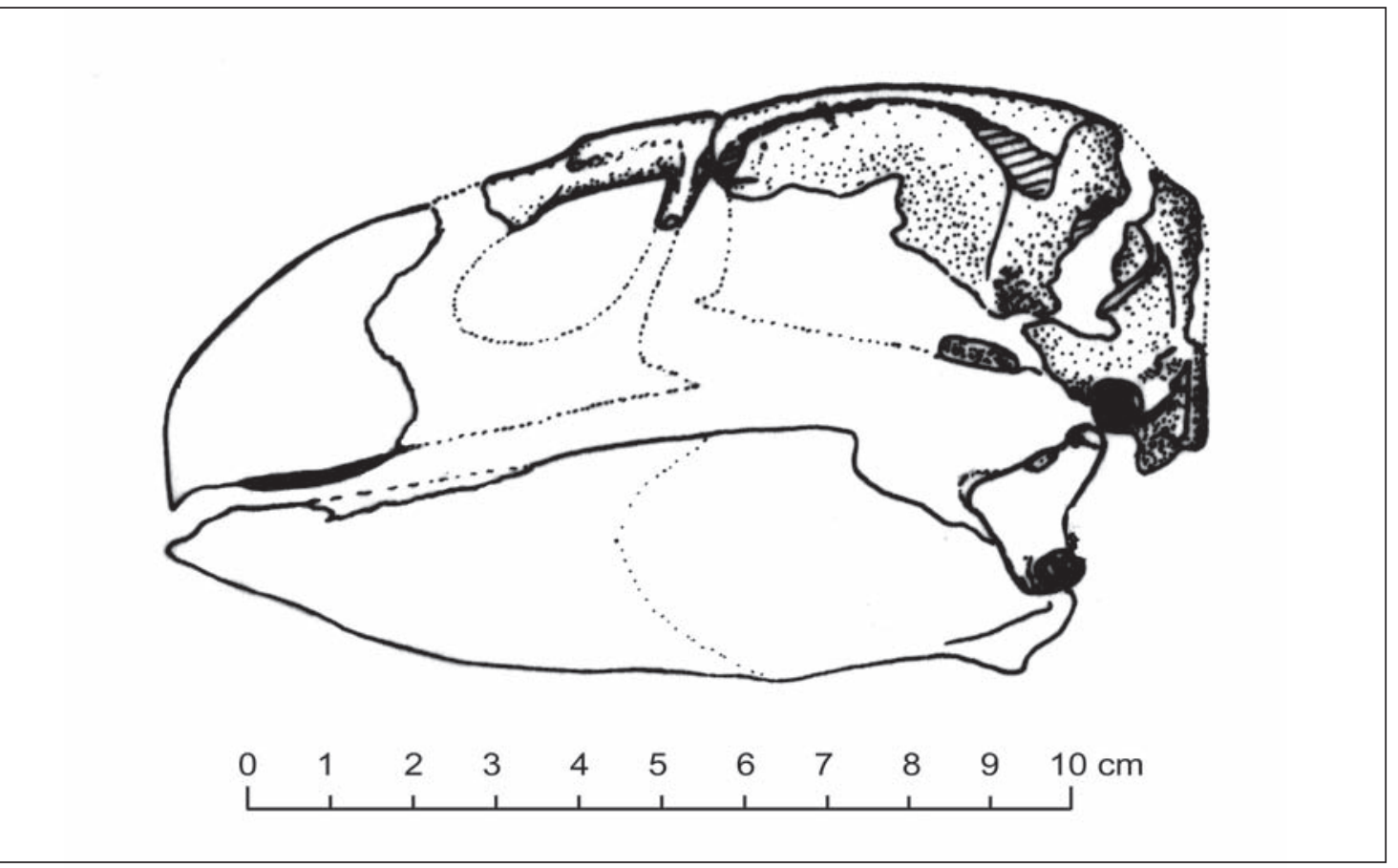

Figure 23. Reconstruction of the skull of Megavitiornis altirostris based on MNZ S37455 and MNZ S37017. Reproduced from Worthy (2000a) with the permission of the Royal Society of New Zealand.

23). A smaller extinct megapode was also found in Volivoli \#1, Qaranivokai and Udit Cave, a flightless or weakly volant form of the widespread genus Megapodius (Jones et al. 1995) named Megapodius amissus (Worthy 2000a). It was larger than all its congeners except $M$. reinwardt in Australia and M. molistructor (Balouet and Olson 1989) extinct of New Caledonia.

The second giant flightless species of bird was a pigeon. Large flightless pigeons are rare in insular faunas (Goodwin 1967): they are otherwise unknown in the Pacific and represented in the Indian Ocean by the dodo Raphus cucullatus and solitaire Pezophaps solitaria. The giant extinct species from Fiji was nearly the same size as the dodo and has been recently described as the new genus and species Natunaornis gigoura (Worthy 2001b), allied to the crowned pigeons Goura of Papua New Guinea. Its genus name honours Kiniviliame Natuna, the senior chief of Volivoli in Nadroga, while its specific name reflects its likeness to a gigantic Goura species. A few bones indicate the presence of a large fruit pigeon, which may be Ducula lakeba, described recently by Worthy (2001b) from Lakeba Island. This species is a larger pigeon than the extinct Ducula david of Wallis Island (Balouet and Olson 1987) and Ducula harrisoni of Henderson Island (Wragg and Worthy 2006), but Viti Levu bones are of either undiagnostic parts or elements not shared with the Lakeba assemblage, precluding a certain referral. However, both the Viti Levu species and Ducula lakeba are larger than any other Ducula so far described.

As might be expected from their remarkable radiation elsewhere in the Pacific (Steadman 1987, 1995, 2006a; Steadman et al. 2000), there are several rails in the Viti Levu fauna, of which three are extinct, and only one was historically known. One is a very distinctive form, recently described as Vitirallus watlingi (Worthy 2004), the long bill of which approaches the proportions of that in Aphanapteryx in the Mascarene Islands, but the bird was the size of the weka Gallirallus australis of New Zealand. Three bones attest to the probable presence of a gallinule, which would not be unexpected given the presence of Gallinula pacifica, historically known from Samoa, and Gallinula silvestris, from the Solomon Islands, both listed in the genus Pareudiastes by Steadman (2006a). Last and rarest of the extinct taxa within the fossil record is the historically extinct Gallirallus (=Nesoclopeus) poicilopterus, of which few bones have been 
found. Four extant rails are also present in the fossil fauna: the banded rail Gallirallus philippensis, the spotless crake Porzana tabuensis, the purple swamphen Porphyrio porphyrio, and the whitebrowed crake Poliolimnas cinereus.

An unexpected discovery was that of a new species of extinct snipe Coenocorypha miratropica, found at Vatumu, near Nadi (Worthy 2003). This genus is otherwise not known from Fiji, but has been recorded in New Caledonia (Balouet and Olson 1989) outside its stronghold in the New Zealand archipelago (Holdaway et al. 2001; Worthy and Holdaway 2002).

Also at Vatumu, a single bone of a small duck Anas sp. was recovered. This is the only anatid fossil so far recovered from Fiji. It is not referable to Dendrocygna arcuata, which is a small, highly vagile species, reported historically from Fiji (Watling 1982). The single scapula is not differentiable from the New Zealand brown teal Anas chlorotis, and so it is possible Fiji had a member of the Australasian radiation to which this species belongs. A teal that is very like Anas gracilis has been recorded from New Caledonia (Balouet and Olson 1989; Worthy unpubl. data).

Fossil sea birds are so far known only from the one fossil site at Vatuma near Nadi. Two petrels, Pterodroma brevipes and Pseudobulweria rostrata, are present in this fauna, which was probably accumulated by a predator, assumed to be the peregrine falcon Falco peregrinus. Clunie (1972) and Worthy (2000b) studied a recent fauna, accumulated by peregrine falcons, found at Joskes Thumb a few kilometres west of Suva. It was dominated by numerous species of birds, including canopy dwellers like Ducula, Vini and Foulehaio, and sea birds such as P. brevipes and Sterna fuscata, and fruit bats, and so was similar to the fauna found at Vatumu. The modern prey faunas of peregrines from Joskes Thumb (Clunie 1972) and downtown Suva (Clunie 1976) clearly show that the peregrine captures prey both over the ocean, outside the reef, and within forests.

Only the sites of Qaranivokai and Vatumu provide data on the volant and canopy species component of the prehuman avifauna. Theses sites have fossils of three fruit pigeons, a ground dove, one or two fruit-doves, the musk parrot, the collared lory and several passerines (Table 2). Only one of these, the largest fruit pigeon, is extinct.

\section{Mammals}

Four species of bats are represented in the fossil faunas (Table 2). These include the large fruit bat Pteropus tonganus, the endemic smaller fruit bat Notopteris macdonaldi, and the small sheath-tailed bat Emballonura semicaudata. A surprise was the discovery of the Fijian mastiff bat Chaerephon bregullae in the Wainibuku site, as this species is now known in the Fiji archipelago only from Vanua Levu and Taveuni (Flannery 1995; Palmeirim et al. 2007), but it is also known from Vanuatu, and a congener Chaerephon solomonis is known from the Solomon Islands (Flannery 1995:406).

No rodents were found in the fossil deposits, but in the archaeological site of Qaranioso \#2 and in the barn owl site at Tavuni (Worthy and Anderson 1999), Rattus praetor was found with R. exulans. Rattus praetor is a Western Pacific species, occurring nearest in Vanuatu, and recorded recently from Mago Island in the Lau Group, Fiji, to which it was presumably taken by human colonisers about 2800 years ago (White et al. 2000). It is now extinct and has been replaced in upper layers of owl sites by Rattus rattus.

\section{Significance of the faunas}

The fossil record of birds throughout the Pacific has revealed many extinct species, and range reductions of others (Steadman 2006a, and references therein). In the New Zealand geographic region, 66, or $26.9 \%$, of the original 245 breeding species are now globally extinct (Holdaway et al. 2001; Worthy and Holdaway 2002: where New Zealand was defined as North, South 
and Stewart Island and associated islets; Chatham Islands; the subantarctic Snares, Bounty, Antipodes, Auckland, Campbell and Macquarie Islands; and the tropical Norfolk Island and Kermadec Islands). At least $41 \%$ of the endemic species from the New Zealand region are extinct. On main islands, losses are even higher, e.g. the North Island lost 51\% of its original fauna (Holdaway et al. 2001; Worthy and Holdaway 2002), and total losses have only been reduced because of the presence of small refuge islands adjacent to larger ones (Holdaway 1999). Gigantism and flightlessness have been significant evolutionary trends on mammalian predatorfree islands, as shown in New Zealand by the 10 species of moa (Dinornithiformes, Tennyson and Martinson 2006), large rail-like birds (Aptornithidae), Aptornis (two species) and waterfowl (Anatidae), Cnemiornis (two species) (Olson and James 1991; Quammen 1996). The Hawaiian archipelago lost more than half its bird diversity (James and Olson 1991; Olson and James 1991), including at least four species of large, flightless, browsing anatids, called moa-nalos. Elsewhere in the Pacific, often up to half the fossil species were found to be extinct (Steadman 2006a), as in the Marquesas (Steadman 1989a; Steadman and Rolett 1996), Easter Island (Steadman 1995), Henderson Island (Wragg and Weisler 1994; Wragg and Worthy 2006; Worthy and Wragg 2003, 2008), Society Islands (Steadman 1989a), Samoa (Steadman 1994), and on the Tongan and Cook Island groups (Steadman 1989a, 1993, 1995). Among the extinct taxa are many species of rails, megapodes, columbids and parrots (Balouet and Olson 1987; Kirchman and Steadman 2005, 2006a, 2006b, 2007; Steadman 1987, 1989b, 1992, 2006a, 2006b, 2006c; Steadman and Zarriello 1987; Wragg and Worthy 2006; Worthy and Wragg 2003, 2008). A similar history of extinction has also been found in New Caledonia (Balouet and Olson 1989) and there are indications of them in Micronesia (Steadman and Intoh 1994; Steadman 2006a). Throughout the Pacific, most of the documented species diversity that has been lost is among the birds, but bats (Koopman and Steadman 1995), lizards (Pregill 1993) and iguanas (Pregill and Dye 1989; Pregill and Steadman 2004) all suffered losses prehistorically.

The recent palaeontological investigations have contributed substantially to knowledge of the prehuman terrestrial fauna of Viti Levu in the Fiji group. A remarkable fauna of large herpetofaunal species (crocodilian, tortoise, iguana and frog) has been revealed (Worthy et al. 1999). The tortoise and the crocodilian (Molnar et al. 2002) have their parallels in Mekosuchus and Meiolania on New Caledonia, Vanuatu and Lord Howe Island. The iguana Lapitiguana impensa (Pregill and Worthy 2003) and the extinct frog Platymantis megabotoniviti (Worthy 2001a) are both substantially larger than the extant taxa in each group, and together consolidate the notion of a long evolutionary history in Fiji for each of these groups. They also typify the phenomenon of island taxa having a tendency to evolve large terrestrial forms that are more at risk of extinction when new animals enter their habitats (Quammen 1996).

To the 47 historically known land birds (Watling 1982), eight more extinct species can be added. These include two of the most remarkable species known from the Central Pacific. Of these, the giant megapode Megavitiornis altirostris was exceeded in size only by Sylviornis of New Caledonia (Poplin and Mourer-Chauviré 1985). The giant, flightless pigeon Natunaornis gigoura represents a unique evolutionary course in the Pacific, but has its parallel in the Mascarene Islands with the solitaire and dodo. While considerably derived, this giant pigeon has several resemblances to Goura from Papua New Guinea (Worthy 2001b). The other extinct species, such as the smaller megapode Megapodius amissus, the large fruit pigeon Ducula cf. lakeba, the duck Anas sp., the three rails, and the snipe Coenocorypha miratropica, all have parallels elsewhere in the Pacific and were to be expected, in view of palaeontological research on other islands (Steadman 1995, 2006a).

Before these discoveries, Fiji was unique among larger Pacific islands in seemingly having lost only two taxa historically, with none known to be lost prehistorically. The new palaeontological 
data show the all-too-familiar pattern seen in insular faunas, that after humans and their commensals colonise an island for the first time there are numerous changes in the fauna, commonly with the large flightless birds and other ground-dwelling taxa becoming extinct (e.g. Olson and James 1991; Quammen 1996; Steadman 1995, 1999, 2006a; Worthy and Holdaway 2002). The large extinct taxa doubtless fell victim to over-hunting by the first humans (Anderson 1996; Quammen 1996). The evidence for this in Viti Levu is still largely lacking, but there is no other plausible reason why large taxa should persist for millennia through many climatic cycles then drop from the record about the time of human arrival. To date, no significant archaeological bone middens of extinct fauna have been recovered from Viti Levu. But Lapitiguana was present in the basal layers of a test pit in the archaeological deposit in Qaranioso near Tau, which is the only inland archaeological site dating to the first contact period of humans with the fauna. A test pit in Volivoli II has revealed one of the extinct rails and small petrels. The archaeological site VL 21/5 on Naigani (Best 1981) contained remains of a giant megapode, as first reported by van Tets (1985) and later by Jones et al. (1995). These bones were identified as Megavitiornis altirostris by Worthy (2000a). There are also bones of the giant iguana Lapitiguana and the crocodilian Volia present in this fauna (Irwin and Worthy in prep). The archaeological record would be immensely enhanced by the discovery of first-contact faunas from sites on Viti Levu. The very small faunas available from these few early sites do attest, however, to the use of some of the extinct taxa by humans, suggesting they had a significant hand in that process.

On Viti Levu, extinction is not just a prehistorical or a historical phenomenon. Viti Levu has the usual range of rodents (Rattus exulans, $R$. rattus, $R$. norvegicus, Mus musculus) found on many islands. These are disastrous enough on their own, but in addition to cats and dogs, Viti Levu has a mustelid, the mongoose, which is a highly efficient predator. The mongoose Herpestes auropunctatus was introduced in 1883 (Pernetta and Watling 1979), and the barred-wing rail Gallirallus (=Nesoclopeus) poecilopterus was probably extinct soon after: the only specimens were collected in the mid-19th century. Since then, the purple swamp hen Porphyrio porphyrio has become extinct on Viti Levu and other islands with mongoose. Moreover, no colonies of petrels are known to survive on Viti Levu, yet Pterodroma brevipes, Pseudobulweria rostrata, Nesofregetta albigularis, Puffinus pacificus and P. lherminieri, at least, are likely to have had breeding populations in the past. The large ground frog Platymantis vitianus is very rare and seemingly headed for extinction on Viti Levu, while remaining common on mongoose-free parts of its former range. Similarly, banded iguanas (Brachylophus spp.) are rare now on Viti Levu, yet can be abundant on predator-free islands. In New Zealand, birds like kaka Nestor meridionalis, kokako Callaeas cinerea, parakeets Cyanoramphus sp. and yellowheads Mohoua ochrocephala are unable to maintain populations in the presence of the stoat Mustela ermina without management of stoat numbers. It is probable that the same is true of several species in Viti Levu, and that the true predatory effects of the mongoose may not yet have been realised. Several birds, notably the pink-billed parrot-finch Erythrura kleinschmidti, the greater forest warbler Trichocichla rufa and the friendly ground dove Gallicolumba stairii are very rare and are likely headed for extinction.

Even bats are not immune from extinction. The fauna from Wainibuku revealed that the Fiji mastiff bat Chaerephon bregullae was formerly on Viti Levu, though presently it is only known from Vanua Levu and Taveuni in Fiji (Palmeirim et al. 2007). While fossils indicate the sheathtailed bat was widespread in Viti Levu even recently, we only saw one individual in Volivoli cave, and since then the species has not been found at all and is now considered extinct on Viti Levu (Palmeirim et al. 2007). Thus, extinction is an ongoing phenomenon on Viti Levu.

These new discoveries shed some light on the origin of the Fiji fauna, and that of Viti Levu in particular. As noted above, the affinities of the Fijian avifauna are generally held to be with Samoa and Tonga (Watling 1982; Steadman and Franklin 2000; Steadman 2006a). However, 
the former presence of the crocodilian, tortoise and three frogs, along with the megapodes and the giant pigeon, all indicate a western relationship for the older, endemic component of the fauna of Viti Levu, as centres of abundance of these taxa and/or their nearest relatives lie to the west. The duck and the snipe probably have an Australasian derivation.

\section{The fossil fauna of Vatulele}

Most of the fossil faunas located in caves on Vatulele arise from predation by the barn owl Tyto alba so most species are its preferred prey. Reptiles were very common in these prey assemblages, with hundreds of geckos present, represented mainly by Gehyra oceanicus and some Nactus pelagicus. Also present were some skinks large enough to be the green tree skink Emoia concolor, rare banded iguanas Brachylophus ?bulabula, and rarely, small boas Candoia bibroni. However, the most obvious component of the owl faunas were rats. Three species were present, with the Pacific rat Rattus exulans most common. The larger, European species $R$. norvegicus and $R$. rattus were always present, clearly indicating that these owl deposits mainly post-dated European arrival. Even the subsurface deposits at Ganilao had large rat bones attributed to $R$. rattus or $R$. norvegicus, and therefore were post-European in age. However, in the small sample from the subsurface deposits, we found a single lower mandible, referred to the Fijian mastiff bat Chaerephon bregullae, now known only from Taveuni.

Only in sites associated with Big Cave entrances 2A and 2B and at Muremure were deposits found that could conceivably pre-date human occupation on the island. In all cases, these were small deposits attributed to single individuals on cave floors.

A total of at least 25 species of birds were recorded as fossil bones from the caves of Vatulele (Table 3). Most of these were in the owl sites. The main birds hunted by the owls were the swiftlet Collocalia spodiopygia, small Ptilinopus doves, Polynesian starling Aplonis tabuensis and wattled honeyeater Foulehaio carunculata. Other regular prey species were kingfishers Halcyon chloris and long-tailed cuckoos Eudynamys taitensis. The common presence of the latter species is interesting, as bones from the species have been not been found on mainland Viti Levu, despite several owl sites having been investigated. Moreover, it is seen only rarely on the main islands of Fiji (D. Watling, pers. comm.). Perhaps it avoids the main islands when it migrates to Fiji. The doves could be either Ptilinopus porphyraceus or P. perousii, both of which are extant on the island. They are of similar size, and the size range of the fossil bones, illustrated by humerus length in Figure 24, has an apparently normal distribution, with a few small individuals. The available reference specimens of $P$. perousii and $P$. porphyraceus fall within the size range of the fossils, which thus could be either. Other than these taxa, the owl preyed on a range of smaller passerines (undetermined) and some coastal species.

Big Cave entrances $2 \mathrm{~A}$ and $2 \mathrm{~B}$ and Muremure Cave provided pitfall faunas, which were dominated by bones of the purple swamp hen Porphyrio porphyrio, typical of the small, slender Pacific races $P$. $p$. vitiensis and $P$. p. samoensis, with the banded rail Gallirallus philippensis also common. No bones of megapodes or those of any other flightless bird were found. No bones of the frog Platymantis spp. were found.

\section{Extinctions on Vatulele}

Few species have demonstrably gone extinct on Vatulele. It seems likely the Fijian mastiff bat lived on the island in the past, and it is presumed extinct there. Of the birds, the swamp hen has gone extinct on Vatulele in living memory, as on Viti Levu. On Vatulele, the mongoose is absent, but the marshy areas are now cultivated, and the swamp hen population may have relied on the mainland population to offset declines in bad seasons. Now that the Viti Levu 
Table 3. A list of the birds, reptiles and mammals from Vatulele Island at present and recorded here as fossils. Data for extant birds is from Dick Watling.

\begin{tabular}{|c|c|c|c|c|}
\hline & Taxon & Common Name & Extant Status & Fossil \\
\hline \multirow[t]{5}{*}{ Reptiles } & Brachylophus?bulabula & Banded iguana & $B$ & $Y$ \\
\hline & Skink, cf. Emoia concolor & Green tree skink & B & Y \\
\hline & Gehyra oceanicus & Oceanic gecko & B & Y \\
\hline & Nactus pelagicus & Pacific slender-toed gecko & B & Y \\
\hline & Candoia bibroni & Pacific boa & B & Y \\
\hline \multirow[t]{36}{*}{ Birds } & Puffinus ?/herminieri & Shearwater sp. & $\mathrm{V}$ & $Y$ \\
\hline & Puffinus pacificus & Wedge-tailed shearwater & V & Y \\
\hline & Pterodroma ?brevipes & Gadfly petrel ?Collared & V & Y \\
\hline & Phaethon lepturus & White-tailed tropic bird & B & $Y$ \\
\hline & Sula dactylatra & Masked booby & B & \\
\hline & Sula leucogaster & Brown booby & v & \\
\hline & Sula sula & Red-footed booby & B & \\
\hline & Fregata ariel & Lesser frigate bird & V & \\
\hline & Ardea novaehollandiae & White-faced heron & $? \mathrm{~B}, \mathrm{~V}$ & \\
\hline & Egretta sacra & Reef heron & B & \\
\hline & Anas superciliosa & Pacific black duck & B & \\
\hline & Circus approximans & Swamp harrier & B & \\
\hline & Gallus gallus & Jungle fowl & B & Y \\
\hline & Gallirallus philippensis & Banded rail & B & Y \\
\hline & Porphyrio porphyrio & Purple swamphen & Locally extinct & Y \\
\hline & Porzana tabuensis & Sooty crake & $?$ & Y \\
\hline & Poliolimnas cinereus & White-browed crake & $?$ & Y \\
\hline & Pluvialis fulva & Pacific golden plover & V & Y \\
\hline & Tringa incana & Wandering tattler & V, common & Y \\
\hline & Tringa brevipes & Siberian tattler & $\mathrm{V}$, rare & \\
\hline & Arenaria interpres & Ruddy turnstone & V & \\
\hline & Limosa lapponica & Bar-tailed godwit & V & \\
\hline & Sterna bergii & Crested tern & V & \\
\hline & Sterna sumatrana & Black-naped tern & B & \\
\hline & Sterna anaethetus & Bridled tern & V & \\
\hline & Anous minutus & Black noddy & $? \mathrm{~B}$ & Y \\
\hline & Anous stolidus & Common noddy & B & Y \\
\hline & Gygis alba & White tern & B & \\
\hline & Columba vitiensis & White-throated pigeon & B & \\
\hline & Ducula pacifica & Pacific pigeon & B & Y \\
\hline & Ptilinopus porphyraceus & Crimson-crowned fruit-dove & B & Y \\
\hline & Ptilinopus perousii & Many-coloured fruit dove & B & \\
\hline & Gallicolumba stairii & Friendly ground dove & ?locally extinct & Y \\
\hline & Streptopelia chinensis & Spotted turtle dove & I & \\
\hline & Vini solitarius & Collared lory & B & \\
\hline & Cacomantis pyrrophanus & Fan-tailed cuckoo & $?$ & Y \\
\hline
\end{tabular}


Table 3 continued

\begin{tabular}{|c|c|c|c|c|}
\hline & Taxon & Common Name & Extant Status & Fossil \\
\hline \multirow[t]{14}{*}{ Birds } & Eudynamys taitensis & Long-tailed cuckoo & $?$ & Y \\
\hline & Tyto alba & Barn owl & B & Y \\
\hline & Collocalia spodiopygia & White-rumped swiftlet & B & Y \\
\hline & Hirundapus caudacutus & Spine-tailed swift/White-throated needletail & V & \\
\hline & Halcyon chloris & Kingfisher & B & Y \\
\hline & Mayrornis lessoni & Slaty monarch & B & \\
\hline & Clytorhynchus vitiensis & Lesser shrikebill & B & $? Y$ \\
\hline & Myiagra vanikorensis & Vanikoro broadbill & B & \\
\hline & ?Zosterops lateralis & Grey-backed white-eye & B & Y \\
\hline & Aplonis tabuensis & Polynesian starling & B & Y \\
\hline & Foulehaio carunculata & Wattled honeyeater & B & Y \\
\hline & Passerine sp. indet. & & & Y \\
\hline & Acridotheres tristis & Common mynah & I & \\
\hline & Acridotheres fuscus & Jungle mynah & I & \\
\hline \multirow[t]{6}{*}{ Mammals } & ?Chaerephon bregullae & ?Fijian mastiff bat & Locally extinct & Y \\
\hline & Emballonura semicaudata & Sheath-tailed bat & B, rare & $Y$ \\
\hline & Pteropus cf. tonganus & Fruit bat & B & $Y$ \\
\hline & Rattus exulans & Pacific rat & B & $Y$ \\
\hline & Rattus rattus & Black rat & B & $Y$ \\
\hline & Rattus norvegicus & Norway rat & B & Y \\
\hline
\end{tabular}

B, breeding; V, visitor; I, introduced species.

\section{Ptilinopus humeri}

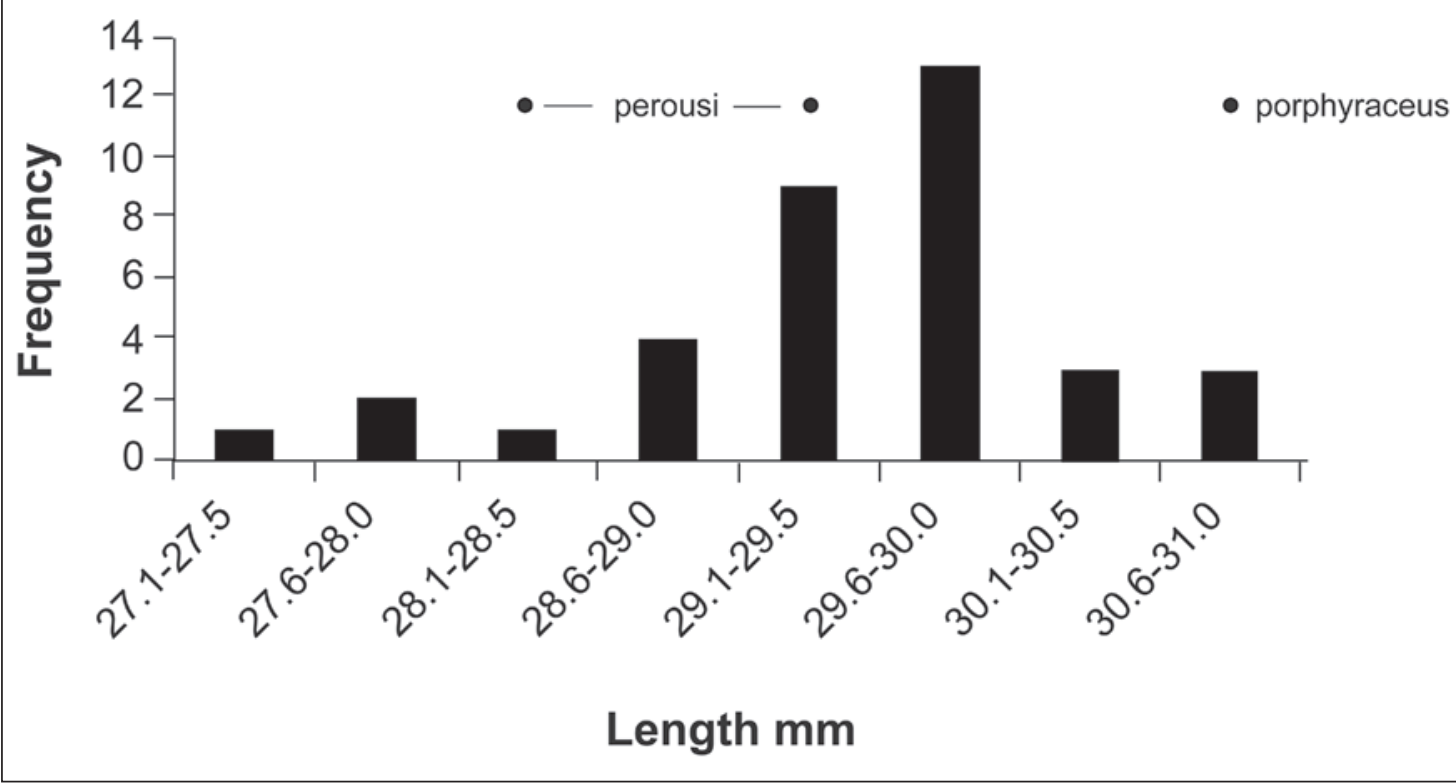

Figure 24. A frequency distribution of humerus length for Ptilinopus humeri from Ganilao plotted with measurements for modern specimens of two P. perousii and one P. porphyraceus. 
population has gone, so has that on Vatulele. The sooty crake probably still lives on the island, though no record exists for it. At least two small rails are seen in the forest near the resort (M. Livingston, pers. comm.), and these are likely to be the banded rail and sooty crake.

The only other possibly extinct bird is the friendly ground dove. This is a shy bird of the forest and it may still be extant in the western forests of the island: Dick Watling's observations of extant fauna were mainly around the resort in the north (D. Watling, pers. comm.). However, the presence of abundant mammalian predators (cats, black rats and Norway rats) militates against this possibility, as this dove has been found to be susceptible to these predators in many other places.

The absence of fossils suggest megapodes were absent from Vatulele, as these groundfrequenting birds surely would have been in the deposits if they were present on the island. Two species of megapodes have been found on Viti Levu, and a further species was present on islands in the Lau Group (Worthy et al. 1999; Worthy 2000a).

\section{Differences from the Viti Levu fauna}

The fossil faunas from Viti Levu include a number of distinctive extinct endemic species. These include a crocodilian, a giant iguana, a new giant frog to add to the two species already known (Worthy 2001a; Worthy et al. 1999), a giant megapode, and another weakly flightless one (Worthy 2000a), a giant flightless pigeon and a new large Ducula species (Worthy 2001b), a new flightless rail Vitirallus watlingi (Worthy 2004), a small duck, and a snipe Coenocorypha miratropica (Worthy 2003). The terrestrial giants and the frogs appear to be or have been restricted to Viti Levu and nearshore islands that were connected to it during low sea levels of the Pleistocene. None of these taxa were recorded from Vatulele, which is about $30 \mathrm{~km}$ distant. The deep intervening water $(>250 \mathrm{~m}$ ) would have ensured Vatulele was an island throughout the Pleistocene glacial-interglacial cycles.

The species that constitute the fauna on Vatulele are all good dispersers. The arboreal iguana, boa, skinks and geckos, for example, could easily have arrived on trees washed down the Sigatoka River during cyclones. Large trees remained on the Vatulele reef in November 1999 from the last cyclone, and Worthy was told they arrived only two days after the storm. The birds are all highly volant taxa, and characteristic of the many small atoll islands in Fiji and elsewhere in the South Pacific (Steadman 2006a). However, the terrestrial species from Viti Levu have not populated Vatulele, so presumably $30 \mathrm{~km}$ of water was an effective barrier.

The lack of any distinct species on Vatulele suggests this island has not been isolated for any great length of time in a form capable of supporting a fauna. In comparison, Henderson Island in the southeast Pacific first emerged only $380 \mathrm{kyr}$ ago (Blake 1995), yet three endemic pigeons and a sandpiper have evolved in that period (Wragg 1995; Wragg and Worthy 2006; Worthy and Wragg 2003, 2008). The lack of any distinct species, particularly of flightless forms, on Vatulele suggests that its subaerial history may be quite short indeed. This provides some support for the relatively recent history of rising land suggested by (Nunn 1998). However, if the true age of Vatulele lies somewhere between the contrasting scenarios outlined above, it is possible that during the last interglacial high stand of sea level, the island was mostly, if not entirely, inundated. Only a small area of the present Naura cliff may have been emergent, an area insufficient to support a diverse terrestrial fauna. Moreover, such a small and low island could have had its fauna periodically removed by storm events. Thus, the present fauna may have a history no older than 70-80 kyr BP. Investigations to better date the antiquity of Vatulele, such as dating the speleothems in the wave-cut notches or in caves, are needed to test this suggestion. 


\section{Appendix: Vatulele fauna from Big Cave, Ganilao, Korolamalama and Muremure}

Trevor H. Worthy

School of Biological, Earth and Environmental Sciences, The University of New South Wales

Appendix: Table 4. Faunas from the fossil sites on Vatulele. Big Cave System. This cave system comprises two discrete sections of cave now separated by collapsed rockfalls. Fossils were found mainly associated with entrances $2 \mathrm{~A}$ and $2 \mathrm{~B}$. The faunas are listed by the sites they were collected from. All fossils were on the surface. Values are NISP/MNI.

\begin{tabular}{|c|c|c|c|c|c|c|c|c|c|}
\hline Taxon & Name & $\begin{array}{l}\text { Entrance } \\
2 A \text { area }\end{array}$ & $\begin{array}{l}\text { SW } \\
\text { passage } \\
\text { off } 2 A\end{array}$ & $\begin{array}{l}\text { 2B, Gavin's } \\
\text { Site }\end{array}$ & $\begin{array}{l}\text { 2B, Talus } \\
\text { slope }\end{array}$ & $\begin{array}{l}\text { 2B, } \\
\text { Isolated } \\
\text { sites }\end{array}$ & $\begin{array}{l}2 B \text {, Dry } \\
\text { rim-stone } \\
\text { pool }\end{array}$ & $\begin{array}{l}\text { 2B, Dry } \\
\text { sandy pool }\end{array}$ & $\begin{array}{l}\text { Big Cave } \\
\text { main Ent. }\end{array}$ \\
\hline Brachylophus fasciatus & Banded iguana & & & $9 / 1$ & & & & & \\
\hline Candoia bibroni & Boa & & & $2 / 1$ & & & & 6 vert & \\
\hline Skink, cf Emoia concolor & Green skink & & & 1 bone & & & & & \\
\hline Gecko sp. indet & Gecko & & & & & & & & Y \\
\hline Puffinus pacificus & $\begin{array}{l}\text { Wedge-tailed } \\
\text { shearwater }\end{array}$ & $17 / 1$ & & & & & & & \\
\hline Porphyrio porphyrio & Purple swamp hen & & $1 / 1,30 / 1$ & $90 / 4$ & $45 / 2$ & $1 / 1$ & $3 / 1$ & $62 / 1, x / 1$ & \\
\hline Gallirallus philippensis & Banded rail & & $\begin{array}{l}6 / 1,16 / 1 \\
2 / 1\end{array}$ & $75 / 5$ & $29 / 3$ & & $45 / 2$ & $34 / 2, x / 1$ & \\
\hline Porzana tabuensis & Sooty crake & & & $5 / 1$ & & & & & \\
\hline Gallus gallus & Chicken & & & & $7 / 1$ & & & & \\
\hline Tyto alba & Barn owl & & & & $2 / 1$ & & & & \\
\hline Ptilinopus porphyraceus & $\begin{array}{l}\text { Crimson-crowned } \\
\text { fruit-dove }\end{array}$ & & & & $3 / 2$ & & & & \\
\hline Gallicolumba stairii & Friendly ground-dove & $1 / 1$ & $2 / 1$ & $2 / 1$ & & $7 / 1,1 / 1$ & & & \\
\hline Eudynamys taitensis & Long-tailed cuckoo & & & & & & & & $21 / 1$ \\
\hline Aplonis tabuensis & Polynesian starling & & $4 / 1$ & & & & & & $1 / 1$ \\
\hline Foulehaio carunculata & Wattled honeyeater & & & & & & & & $1 / 1$ \\
\hline Passerine sp. indet. & & & & Yes & Yes & & & & Yes \\
\hline Pteropus tonganus & Fruit bat & 1 dentary & & & & & & & \\
\hline Emballonura semicaudata & Sheath-tailed bat & & & 7 bones & & & & 20 bones & 28 bones \\
\hline Rattus exulans & Pacific rat & & Y & 74 bones & 196 bones & & 53 bones & & Skeleton \\
\hline Rattus rattus & Black rat & & Y & & & & & & \\
\hline Rattus rattus /norvegicus & Norway rat & Y & & 12 bones & 30 bones & & 5 bones & & \\
\hline
\end{tabular}


Appendix: Table 4 continued. List of species from the Ganilao barn owl midden. Faunas are listed here from the five separate samples. Values are NISP/MNI.

\begin{tabular}{|c|c|c|c|c|c|c|}
\hline Taxon & Common name & Surface & Test pit $0-5 \mathrm{~cm}$ & Test pit 5-10 cm & Test pit $10-15 \mathrm{~cm}$ & Damp alcove \\
\hline Brachylophus fasciatus & Banded iguana & $28 / 1$ & & & & 9 bones \\
\hline Skink, cf Emoia concolor & Green tree skink & 34 bones & & & 1 bone & 1 bone \\
\hline Gehyra oceanicus & Oceanic gecko & $100 s / 94$ & 30 bones & 10 bones & 8 bones & $68 / 6$ \\
\hline Nactus pelagicus & Pacific slender-toed gecko & $x / 26$ & & & & 3 bones \\
\hline Gecko species & & & & & & $\mathrm{X} / 2$ \\
\hline Puffinus sp. ?herminieri & ?Audubon's shearwater & & & & & $1 / 1$ \\
\hline Pterodroma?brevipes & White-winged petrel & $5 / 2$ & & & $4 / 1$ & \\
\hline Phaethon lepturus & White-tailed tropic bird & $7 / 2$ & & & & \\
\hline Pluvialis fulva & Lesser golden plover & $4 / 1$ & & & & \\
\hline Anous minutus & Black noddy & $5 / 1$ & & $2 / 1$ & $1 / 1$ & $1 / 1$ \\
\hline Anous stolidus & Common noddy & $8 / 4$ & & & $2 / 1$ & $14 / 4$ \\
\hline Tringa incana. & Wandering tattler & $2 / 1$ & & $1 / 1$ & & \\
\hline Gallirallus philippensis & Banded rail & $25 / 6$ & & & & $7 / 2$ \\
\hline Porzana tabuensis & Sooty crake & & & & & $2 / 1$ \\
\hline Poliolimnas cinereus & White-browed crake & $4 / 1$ & & & & \\
\hline Tyto alba & Barn owl & $2 / 1$ & & & & \\
\hline Ducula pacifica & Pacific pigeon & $9 / 2$ & $1 / 1$ & & & \\
\hline Ptilinopus porphyraceus & Crimson-crowned fruit-dove & $447 / 33$ & $11 / 2$ & $1 / 1$ & & $46 / 5$ \\
\hline Gallicolumba stairii & Friendly ground dove & $54 / 6$ & & & & $12 / 3$ \\
\hline Cacomantis pyrrophanus & Fan-tailed cuckoo & & $3 / 2$ & & & \\
\hline Eudynamys taitensis & Long-tailed cuckoo & $66 / 7$ & $4 / 1$ & & & $13 / 3$ \\
\hline Halcyon chloris & Kingfisher & $31 / 5$ & $1 / 1$ & & $2 / 1$ & $9 / 2$ \\
\hline Collocalia spodiopygia & Swiftlet & 451 bones & 20 bones & 9 bones & 8 bones & 81 bones \\
\hline Aplonis tabuensis & Polynesian starling & $158 / 15$ & $3 / 1$ & $2 / 1$ & $2 / 1$ & $13 / 3$ \\
\hline Foulehaio carunculata & Wattled honeyeater & $87 / 8$ & & & & $3 / 1$ \\
\hline ?Zosterops lateralis & Grey-backed white-eye & $4 / 1$ & & & & $6 / 2$ \\
\hline ?Clytorhynchus vitiensis & Lesser shrikebill & & & & & $1 / 1$ \\
\hline Passerine sp. & & $2 \mathrm{spp}$ & Yes & & & Yes \\
\hline ?Chaerephon bregullae & ?Fijian mastiff bat & & & R dentary & & \\
\hline Emballonura semicaudata & Sheath-tailed bat & 120 bones & 7 bones & 1 bone & 4 bones & 11 bones \\
\hline Rattus exulans & Pacific rat & $X / 100 s$ & $100 s / 20$ & $100 \mathrm{~s} / 5$ & $\mathrm{X} / 1$ & $100 \mathrm{~s}$ \\
\hline Rattus rattus & Black rat & $X / 23$ & & & & $X / 1$ \\
\hline Rattus norvegicus & Norway rat & $X / 10$ & & & & $X / 3$ \\
\hline Rattus rattus /norvegicus & Black or Norway rat & & 30 bones & 6 bones & & \\
\hline
\end{tabular}


58 Trevor H. Worthy and Atholl Anderson

Appendix: Table 4 continued. List of specimens from Korolamalama Cave owl midden. Values are NISP/MNI.

\begin{tabular}{lll}
\hline Taxon & Common name & Specimens \\
\hline Gehyra oceanicus & Oceanic gecko & $100+$ \\
Nactus pelagicus & Pacific slender-toed gecko & 1 \\
Gallirallus philippensis & & \\
Gallus gallus & Banded rail & $2 / 1$ \\
Tyto alba & Chicken & $9 / 1$ \\
Ptilinopus porphyraceus & Barn owl & $8 / 1$ juv \\
?Cacomantis pyrrophanus & Crimson-crowned fruit-dove & $90 / 11$ \\
Aplonis tabuensis & ?Fan-tailed cuckoo & $4 / 1$ \\
Foulehaio carunculata & Polynesian starling & $75 / 7$ \\
Passerine sp. & Wattled honeyeater & $51 / 6$ \\
& & Yes \\
Emballonura semicaudata & & Pacific rat \\
Rattus exulans & Black rat & 30 bones \\
Rattus rattus & Norway rat & $100 \mathrm{~s}$ \\
Rattus norvegicus & & $\mathrm{Xil}$ \\
\hline
\end{tabular}

Appendix: Table 4 continued. List of faunas from Muremure Cave. Fossils are listed under each discrete site they were found in. Values are NISP/MNI.

\begin{tabular}{|c|c|c|c|c|c|c|c|}
\hline Taxon & Common name & Site 1 & Site 2 & Site 3 & Site 4 & Site 5 & Owl site \\
\hline Brachylophus fasciatus & Banded iguana & & $1 / 1$ & & & & \\
\hline Porphyrio porphyrio & Purple swamp hen & $27 / 2$ & & $30 / 1$ & $3 / 1,1 / 1$ & $22 / 1$ & \\
\hline Gallirallus philippensis & Banded rail & $7 / 2$ & & & & $4 / 1$ & \\
\hline Porzana tabuensis & Sooty crake & & & $3 / 1$ & & & \\
\hline Tyto alba & Barn owl & & & & & & $12 / 2$ \\
\hline Ptilinopus porphyraceus & Crimson-crowned fruit-dove & & & & & & $9 / 2$ \\
\hline Gallicolumba stairii & Friendly ground dove & & $5 / 1$ & & & & \\
\hline Eudynamys taitensis & Long-tailed cuckoo & & & & & & $3 / 1$ \\
\hline Aplonis tabuensis & Polynesian starling & & & & & & $4 / 1$ \\
\hline Foulehaio carunculata & Wattled honeyeater & & & & & & $3 / 2$ \\
\hline Rattus exulans & Pacific rat & & & & & & 40 bones \\
\hline Rattus rattus/norvegicus & Black or Norway rat & & & & & & 23 bones \\
\hline
\end{tabular}




\section{References}

Anderson, A.J. 1996. Te whenua hou: Prehistoric Polynesian colonisation of New Zealand and its impact on the environment. In: Hunt, T.H. and Kirch, P.V. (eds), Historical ecology in the Pacific Islands, pp. 271-283. Yale University Press, Yale.

Anderson A.J. and Clark, G.R. 1999. The age of Lapita settlement in Fiji. Archaeology in Oceania 34: 31-39.

Anderson, A.J., Clark, G. and Worthy, T.H. 2000. An inland Lapita site in Fiji. Journal of the Polynesian Society 109: 311-316.

Balouet, J.C. 1991. The fossil vertebrate record of New Caledonia. In: Rich, P.V., Monaghan, J.M., Baird, R.F., Rich, T.H., Thompson, E.M. and Williams, C. (eds), Vertebrate palaeontology of Australasia, pp. 1383-1409. Pioneer Design Studio, Melbourne.

Balouet, J.C. and Buffetaut, E. 1987. Mekosuchus inexpectatus n. g., n. sp., Crocodilien nouveau de l'Holocene de Nouvelle Caledonie. Comptes Rendus de l'Academie des Sciences, Paris 304: 853-857.

Balouet, J.C. and Olson, S.L. 1987. An extinct species of giant pigeon (Columbidae: Ducula) from archaeological deposits on Wallis (Uvea) Island, South Pacific. Proceedings of the Biological Society of Washington 100(4): 769-775.

Balouet J.C. and Olson, S.L. 1989. Fossil birds from late Quaternary deposits in New Caledonia. Smithsonian Contributions to Zoology 469: 1-38.

Baumel, J.J. and Witmer, L.M. 1993. Osteologia. In: Baumel, J.J., King, A.S., Breazile, J.E., Evans, H.E and Vanden Berge, J.C. (eds), Handbook of avian anatomy: Nomina Anatomica Avium, pp. 45-132, Second Edition. Publications of the Nuttall Ornithological Club 23. Cambridge, Massachusetts.

Best, S. 1981. Excavations at site VL 21/5, Naigani Island, Fiji. A preliminary report. Department of Anthropology, University of Auckland.

Blake, S.G. 1995. Late Quaternary history of Henderson Island, Pitcairn Group. Biological Journal of the Linnean Society 56: 43-62. [Reprinted as: The Pitcairn Islands: Biogeography, ecology and prehistory. Edited by Benton, T.G. and Spencer, T., Academic Press, 1995]

Clunie, F. 1972. A contribution to the natural history of the Fiji peregrine. Notornis 19: 302-322.

Clunie, F. 1976. A Fiji peregrine (Falco peregrinus) in an urban-marine environment. Notornis 23: 8-28.

Flannery, T.F. 1995. Mammals of the South-west Pacific and Moluccan Islands. Reed Books in association with the Australian Museum.

Goodwin, D. 1967. Pigeons and doves of the world. Trustees of the British Museum (Natural History), London.

Holdaway, R.N. 1999. Introduced predators and avian extinction in New Zealand. In: MacPhee, R.D.E. (ed), Extinctions in near time: Causes, contexts, and consequence, pp. 189-238. Advances in Paleobiology. Plenum Press, New York.

Holdaway, R.N., Worthy, T.H. and Tennyson, A.J.T. 2001. A working list of breeding bird species of the New Zealand region at first human contact. New Zealand Journal of Zoology 28(2): 119-187.

James, H.F. and Olson, S.L. 1991. Descriptions of thirty-two new species of birds from the Hawaiian Islands: Part 2. Passeriformes. Ornithological Monographs 46: 1-88.

Jones, D.N., Dekker, R.W.R.J. and Roselaar, C.S. 1995. The megapodes, Megapodiidae. Bird families of the World, Oxford University Press.

Keogh, J.S., Edwards, D.L., Fisher, R.N. and Harlow, P.S. 2008. Molecular and morphological analysis of the critically endangered Fijian iguanas reveals cryptic diversity and a complex biogeographic history. Philosophical Transactions of the Royal Society of London B 363: 3413-3426.

Kirchman, J.J. and Steadman, D.W. 2005. Rails (Aves: Rallidae: Gallirallus) from prehistoric sites in the Kingdom of Tonga, including a description of a new species. Proceedings of the Biological Society of Washington 118: 465-477.

Kirchman, J.J. and Steadman, D.W. 2006a. New species of rails (Aves: Rallidae) from an archaeological site on Huahine, Society Islands. Pacific Science 60: 281-297.

Kirchman, J.J. and Steadman, D.W. 2006b. Rails (Rallidae: Gallirallus) from prehistoric archaeological sites in Western Oceania. Zootaxa 1316: 1-31. 
Kirchman, J.J. and Steadman, D.W. 2007. New species of extinct rails (Aves: Rallidae) from archaeological sites in the Marquesas Islands, French Polynesia. Pacific Science 61: 145-163.

Koopman, K.F. and Steadman, D.W. 1995. Extinction and biogeography of bats on 'Eua, Kingdom of Tonga. American Museum Novitates 3125: 1-13.

Livezey, B.C. 1993. An ecomorphological review of the dodo (Raphus cucullatus) and solitaire (Pezophaps solitaria), flightless Columbiformes of the Mascarene Islands. Journal of Zoology London 230: 247-292.

Mead, J.I., Steadman, D.W., Bedford, S.H., Bell, C.J. and Spriggs, M. 2002. New extinct mekosuchine crocodile from Vanuatu, South Pacific. Copeia 2002(3): 632-641.

Molnar, R.E., Worthy, T.H. and Willis, P.M.A. 2002. An extinct Pleistocene endemic Mekosuchine crocodylian from Fiji. Journal of Vertebrate Paleontology 22(3): 612-628.

Nunn, P.D. 1998. Uplift of islands along the Vatulele-Beqa ridge. In: Pacific Island landscapes. Institute of Pacific Studies, The University of the South Pacific, Suva, Fiji.

Olson, S.L. and James, H.F. 1991. Descriptions of thirty-two new species of birds from the Hawaiian Islands: Part 1. Non-Passeriformes. Ornithological Monographs 45: 1-88.

Palmeirim, J.M., Champion, A., Naikatini, A., Niukula, J., Tuiwawa, M., Fisher, M., Yabaki-Gounder, M., Thorsteinsdóttir, S., Qalovaki, S. and Dunn, T. 2007. Distribution, status and conservation of the bats of the Fiji Islands. Oryx 41(4): 509-519.

Pernetta, J.C. and Watling, D. 1979. The introduced and native terrestrial vertebrates of Fiji. Pacific Science 32: 223-244.

Poplin, F. and Mourer-Chauviré, C. 1985. Sylviornis neocaledoniae (Aves, Galliformes, Megapodiidae), Oiseau géant éteint de L'ile des Pins (Nouvelle-Caledonie). Geobios 18: 73-97.

Pregill, G.K. 1993. Fossil lizards from the late Quaternary of 'Eua, Tonga. Pacific Science 47: 101-114.

Pregill, G.K. and Dye, T. 1989. Prehistoric extinction of giant iguanas in Tonga. Copeia 1989: 505-508.

Pregill, G.K. and Steadman, D.W. 2004. Human-altered diversity and biogeography of South Pacific iguanas. Journal of Herpetology 38: 15-21.

Pregill, G.K. and Worthy, T.H. 2003. A new iguanid lizard (Squamata, Iguanidae) from the late Quaternary of Fiji, Southwest Pacific. Herpetologica 59: 57-67.

Quammen, D. 1996. The song of the dodo. Island biogeography in an age of extinction. Hutchinson, London.

Steadman, D.W. 1987. Two new species of rails (Aves: Rallidae) from Mangaia, Southern Cook Islands. Pacific Science 40: 27-43.

Steadman, D.W. 1989a. Extinction of birds in Eastern Polynesia: A review of the record, and comparisons with other Pacific Island groups. Journal of Archaeological Science 16: 177-205.

Steadman, D.W. 1989b. New species and records of birds (Aves: Megapodiidae, Columbidae) from an archaeological site on Lifuka, Tonga. Proceedings of the Biological Society of Washington 102(3): 537-552.

Steadman, D.W. 1992. New species of Gallicolumba and Macropygia (Aves: Columbidae). Los Angeles County Museum of Natural History, Science Series 36: 329-348.

Steadman, D.W. 1993. Biogeography of Tongan birds before and after human impact. Proceedings of the National Academy of Sciences U.S.A. 90: 818-822.

Steadman, D.W. 1994. Bird bones from the To'aga site, Ofu, American Samoa: Prehistoric loss of seabirds and megapodes. University of California Archaeological Research Facility, Contributions 51: 217-228.

Steadman, D.W. 1995. Prehistoric extinctions of Pacific island birds: Biodiversity meets zooarchaeology. Science 267: 1123-1131.

Steadman, D.W. 1999. The biogeography and extinction of megapodes in Oceania. In: Dekker, R.W.R.J., Jones, D.N. and Benshemesh, J. (eds), Proceedings of the Third International Megapode symposium. Zoologische Verhandelingen Leiden 327: 7-21.

Steadman, D.W. 2006a. Extinction and biogeography of tropical Pacific birds. The University of Chicago Press, Chicago and London. 
Steadman, D.W. 2006b. A new species of extinct parrot (Psittacidae: Eclectus) from Tonga and Vanuatu, South Pacific. Pacific Science 60: 137-145.

Steadman, D.W. 2006c. An extinct species of tooth-billed pigeon (Didunculus) from the Kingdom of Tonga, and the concept of endemism in insular landbirds. Journal of Zoology 268: 233-241.

Steadman, D.W. and Franklin, J. 2000. A preliminary survey of landbirds on Lakeba, Lau Group, Fiji. Ети 100: 227-235.

Steadman, D.W. and Intoh, M. 1994. Biogeography and prehistoric exploitation of birds from Fais Island, Yap State, Federated States of Micronesia. Pacific Science 48: 116-135.

Steadman, D.W. and Rolett, B. 1996. A chronostratigraphic analysis of landbird extinction on Tahuata, Marquesas Islands. Journal of Archaeological Science 23: 81-94.

Steadman, D.W., Worthy, T.H., Anderson, A.J. and Walter, R. 2000. New species and records of birds from prehistoric sites on Niue, Southwest Pacific. Wilson Bulletin 112(2): 165-186.

Steadman, D.W. and Zarriello, M.C. 1987. Two new species of parrots (Aves: Psittacidae) from archaeological sites in the Marquesas Islands. Proceedings of the Biological Society of Washington 100: 518-528.

Tennyson, A. and Martinson, P. 2006. Extinct birds of New Zealand. Te Papa Press, Wellington.

Van Tets, G.F. 1985. Progura gallinacea The giant Australian megapode. In: Rich, P.V., Van Tets, G.F. and Knight F. (eds), Kadimakara extinct vertebrates of Australia, pp. 195-199. Pioneer Design Studio, Victoria.

Watling, D. 1982. Birds of Fiji, Tonga and Samoa. Millwood Press, Wellington.

White, J.P., Clark, G. and Bedford, S. 2000. Distribution, present and past, of Rattus praetor in the Pacific and its implications. Pacific Science 54(2): 105-117.

Worthy, T.H. 2000a. The fossil megapodes (Aves: Megapodiidae) of Fiji with descriptions of a new genus and two new species. Journal of the Royal Society of New Zealand 30: 337-364.

Worthy, T.H. 2000b. The prey of peregrine falcons Falco peregrinus as determined by skeletal remains from Joske's Thumb, Viti Levu. Domodomo 12(2)[1999]: 44-48.

Worthy, T.H. 2001a. A new species of Platymantis (Anura: Ranidae) from Quaternary deposits on Viti Levu, Fiji. Paleontology 44(4): 665-680.

Worthy, T.H. 2001b. A giant flightless pigeon gen. et sp. nov. and a new species of Ducula (Aves: Columbidae), from Quaternary deposits in Fiji. Journal of the Royal Society of New Zealand 31: 763-794.

Worthy, T.H. 2003. A new extinct species of snipe Coenocorypha from Viti Levu, Fiji. Bulletin of the British Ornithologists' Club 123(2): 90-103.

Worthy, T.H. 2004. The fossil rails (Aves: Rallidae) of Fiji with descriptions of a new genus and species. Journal of the Royal Society of New Zealand 34(3): 295-314.

Worthy, T.H. and Anderson, A. 1999. Research on the caves of Viti Levu, Fiji, June 1997 - October 1998, and their significance for palaeontology and archaeology. Report to the Fiji Museum, ANH, RSPAS, ANU, Canberra, ACT 0200, Australia.

Worthy, T.H., Anderson, A.J. and Molnar, R.E. 1999. Megafaunal expression in a land without mammals - the first fossil faunas from terrestrial deposits in Fiji (Vertebrata: Amphibia, Reptilia, Aves). Senckenbergiana biologica 79(2): 237-242.

Worthy, T.H. and Holdaway R.N. 2002. The lost world of the moa: Prehistoric life of New Zealand. Indiana University Press, Indiana.

Worthy, T.H., Walter, R. and Anderson, A.J. 1998. Fossil and archaeological avifauna of Niue. Notornis 45: 177-190.

Worthy, T.H., Wilde, K. and Williams, D. 1991. Anahulu Cave, Tongatapu. New Zealand Speleological Bulletin 8: 525-528.

Worthy, T.H. and Wragg, G.M. 2003. A new species of Gallicolumba: Columbidae from Henderson Island, Pitcairn Group. Journal of the Royal Society of New Zealand 33: 769-793.

Worthy, T.H. and Wragg, G.M. 2008. A new genus and species of pigeon (Aves: Columbidae) from Henderson Island, Pitcairn Group. In: Clark, G.R., Leach, F. and O'Connor, S. (eds), Islands 
of inquiry: Colonisation, seafaring and the archaeology of maritime landscapes, pp. 499-510. Terra Australis 29. ANU EPress, Canberra.

Wragg, G.M. 1995. The fossil birds of Henderson Island, Pitcairn Group: Natural turnover and human impact. Biological Journal of the Linnean Society 56: 405-414. [Reprinted as: The Pitcairn Islands: Biogeography, ecology and prehistory. Edited T. G. Benton and T. Spencer. Academic Press, 1995.]

Wragg, G.M. and Weisler, M.I. 1994. Extinctions and new records of birds from Henderson Island, Pitcairn Group, South Pacific Ocean. Notornis 41: 61-70.

Wragg, G.M. and Worthy, T.H. 2006. A new species of extinct imperial pigeon (Ducula: Columbidae) from Henderson Island, Pitcairn Group. Historical Biology 18(2): 127-140. 